\title{
WAHHABIS, SUFIS AND SALAFIS IN EARLY TWENTIETH CENTURY DAMASCUS
}

\author{
David Commins
}

For the past two centuries, observers of the Muslim world have frequently traced religious purification campaigns to Wahhabi influence. For instance, British authorities in nineteenth-century India perceived Wahhabi-tinged movements from Bengal to Punjab. ${ }^{1}$ Russian journalists presently use the term "Wahhabi" for just about any manifestation of religious assertion in nearby Muslim lands. ${ }^{2}$ Of course, the Arabian reformers have striven to export their doctrine, but there is little careful research on the local reception of Wahhabism in different parts of the Muslim world. This study examines how allegations of Wahhabi influence became a point of controversy between rival camps of religious scholars in early twentieth century Damascus. Thus the focus here is not on tracing Wahhabi influence but on what "Wahhabi" meant in that context and how it was used in the polemics contained in religious treatises published between 1900 and the early 1920s. From these works, it appears that the Wahhabi issue and local religious discourse evolved over time. A pair of essays published in 1900 and 1901 repeat the standard anti-Wahhabi arguments handed down since the eighteenth century, while essays published between 1909 and the early 1920s (spanning the Ottoman constitutional and early French mandate years) indicate significant shifts in discourse and context.

${ }^{1}$ Qeyamuddin Ahmad remarks on British colonial authorities in India using the Wahhabi label as a synonym for "traitor" or "rebel," in The Wahhabi Movement in India, 2nd ed., Manohar 1994, pp. ix-x.

${ }^{2}$ Muriel Atkin, "The Rhetoric of Islamophobia," Central Asia and the Caucasus 1 (2000), pp. 123-132; Alexander Knysh, "A Clear and Present Danger: 'Wahhabism' as a Rhetorical Foil," Saudi-American Forum 24 (14 November 2003); Adeeb Khalid, "A Secular Islam: Nation, State, and Religion in Uzbekistan," International Journal of Middle East Studies 35 (2003), pp. 581, 587-591. 


\section{EARLy Responses to WaHhabism}

A model study of Wahhabism's reception in one locality is Bernard Haykel's splendid monograph on the Yemeni scholar Muhammad alShawkani. He points to a number of similarities between the views and ideas of al-Shawkani and the Wahhabis regarding illegitimate innovations (bida) in the cult of saints and types of idolatry (shirk), at the same he notes that they were not identical. Moreover, Haykel situates al-Shawkani's intellectual positions firmly in the context of the political and religious dynamics in Yemen rather than viewing them as a result of Wahhabi influence. The gaps between Wahhabi condemnation of all practices associated with tomb visits and al-Shawkani's allowance for practices he considered permissible were substantial and irreconcilable. The Wahhabi call did not convert the leading scholar in early nineteenth century Yemen. ${ }^{3}$

In the case of Syria, and more specifically Damascus, religious scholars, or 'ulama', greeted the Wahhabi call with unremitting hostility until the late nineteenth century for doctrinal and political reasons. First, Muhammad ibn 'Abd al-Wahhab's views on monotheism, idolatry, and excommunication clashed with the longstanding consensus among the 'ulama'. He viewed Muslims who participated in popular customs associated with the cult of saints and in various intercessionary behaviors as idolaters whose lives, honor, and property were legitimate spoils. His critics responded with two kinds of arguments. Some defended the permissibility of practices that Ibn 'Abd al-Wahhab considered idolatry. Others admitted that such practices violated the command to devote all worship to God, but maintained that such violation did not render one an idolater. ${ }^{4}$

The political reason for hostility toward Wahhabism was that its association with Saudi power made it suspect from the Ottoman perspective. The first Saudi state (1744-1818) had denied the legitimacy of the Ottoman sultan and expelled the Ottomans from the holy cities of Mecca and Medina in the early 1800s. The Ottomans launched a counterattack in 1811 to regain the holy cities. In 1818, the Ottoman offensive concluded with the destruction of the first Saudi capital and

\footnotetext{
${ }^{3}$ Bernard Haykel, Revival and Reform in Islam: The Legacy of Muhammad alShawkani, Cambridge 2003, pp. 127-138.

${ }^{4}$ The doctrinal arguments were of course far more extensive, but this was the core of the controversy.
} 
the capture and exile of Saudi and Wahhabi leaders. Nevertheless, the Saudis came back to power after Ottoman forces withdrew from Arabia. Rulers of the second Saudi state adopted a more cautious attitude toward the Ottoman Empire, realizing the folly of provocation. Wahhabi 'ulama', however, maintained a consistent posture of enmity toward the outside world as the abode of idolatry that must be avoided in order to maintain the purity of their own abode of Islam; and Ottoman 'ulama' kept up a polemical campaign against the Najdi doctrine. ${ }^{5}$ Wahhabism's critics included prominent Hanbali 'ulama' of Damascus and Sufi authors from Baghdad. ${ }^{6}$ Nevertheless, because of new intellectual developments in the late 1800s, we find a handful of Ottoman 'ulama' in Baghdad and Damascus revising the standard view of Wahhabis as ignorant doctrinal extremists. ${ }^{7}$

\section{The Salafi-Wahhabi Connection}

This reappraisal of the Wahhabis was undertaken by 'ulama' in the Salafi movement. While both Ottoman Salafis and Wahhabis claimed to possess correct understanding of Islam as practiced by the pious ancestors (al-salafal-salih), they did not concur on what that meant exactly. Thus the Ottoman Salafis displayed a modernist bent as they explored ways to reconcile Islam with European concepts of modern science, legal rationality, and constitutional government. In these respects, they differed from the Wahhabis, who then viewed all borrowings from infidels as forbidden. Nevertheless, the two self-avowed followers of the pious ancestors converged when it came to campaigning against religious practices and beliefs that they regarded as illegitimate innovations, especially practices associated with popular Sufi orders and the shrines of saints. They also concurred in their respect for the views of the medieval scholar Taqi al-Din Ibn Taymiyya, and they collaborated in efforts to revive his works. Salafis in Syria and Iraq established contacts with

${ }^{5}$ David Commins, The Wahhabi Mission and Saudi Arabia, London, 2006, pp. 44-50, 56-61, 63-65; Itzchak Weismann, Taste of Modernity: Sufism, Salafiyya and Arabism in Late Ottoman Damascus, Leiden 2001, pp. 53-54, 73-74.

${ }^{6}$ On the Hanbali scholar Hasan al-Shatti in Damascus, see Weismann, Taste of Modernity, pp. 66-67; on Da'ud ibn Jirjis al-Naqshbandi in Baghdad, see Da'ud ibn Sulayman ibn Jirjis, Sulh al-ikhwan min ahl al-iman, Bombay 1888-89.

${ }^{7}$ On reappraisals of the Wahhabis by the Baghdad Alusis and Rashid Rida, see Commins, The Wahhabi Mission, pp. 131-140. 
Wahhabi scholars and students through Najdi merchants handling the caravan trade between Arabia and the Fertile Crescent. Correspondence from the early 1900s between two leading Salafis, Jamal al-Din al-Qasimi of Damascus and Mahmud Shukri al-Alusi of Baghdad, reveals a network of 'ulama' and merchants in Damascus, Baghdad, Najd, Jeddah, Bahrain, and Qatar. The letters show that Najdi merchants funded the publication not only of works by Ibn Taymiyya but also of a treatise by al-Qasimi. ${ }^{8}$ They also show that al-Alusi completed an unfinished manuscript by a leading Wahhabi shaykh rebutting the Baghdad Sufi Da'ud ibn Jirjis al-Naqshbandi. ${ }^{9}$

When defenders of Sufism responded to Salafi critics, they naturally resorted to religious texts that justified their practices and beliefs, but there was also a political dimension to their rebuttals. Ottoman Sultan Abdülhamid II patronized Sufi orders to strengthen loyalty to Istanbul, and this policy was effective in the Arab provinces. ${ }^{10}$ Hence one might construe criticism of Sufi practices as a slight to the sultan's religious prestige. The political aspect assumed another dimension in 1902, when a Saudi chief, 'Abd al-'Aziz ibn Sa ud, captured Riyadh, inaugurating his long struggle to reconquer Najd from Istanbul's vassals, the Rashidis. Around that time, rumors circulated of plots to separate Syria from the Ottoman Empire. Officials in Istanbul therefore became alarmed at the prospect of an alliance between the Saudi-Wahhabi cause and Salafi religious reformers. That made it natural for 'ulama' opposed to the Salafis to incite Ottoman authorities to persecute them on the grounds that they were spreading Wahhabism, identified with the politically suspect Ibn Sa ud. ${ }^{11}$

The emergence of 'ulama' defending Wahhabis in the first two decades of the twentieth century coincided with a contemporary reappraisal of the Arabian nomads. Birgit Schaebler has observed how the Syrian

\footnotetext{
${ }^{8}$ Muhammad ibn Nasir al-'Ajami, al-Rasa'il al-mutabadala bayna Jamal al-Din alQasimi wa-Mahmud Shukri al-Alusi, Beirut 2001, pp. 10, 41-43, 47, 61-64, 136 n. 1.

${ }^{9}$ Fath al-manan tatimmat minhaj al-ta'sis radd sulh al-ikhwan. The Wahhabi author 'Abd al-Latif ibn Hasan $\mathrm{Al}$ al-Shaikh had not finished the treatise when he died. The treatise with Alusi's additions was published in 1309 (1891/92). Al-'Ajami, al-Rasa'il al-mutabadala, p. 114. For a discussion of the Baghdad Sufi Da'ud ibn Jirjis and the Alusis, see Itzchak Weismann, "The Naqshbandiyya-Khalidiyya and the Salafi Challenge in Iraq," Journal of the History of Sufism 4 (2004), pp. 234-238.

${ }^{10}$ Selim Deringil, The Well-Protected Domains: Ideology and the Legitimization of Power in the Ottoman Empire, 1876-1909, London 1998, pp. 63-66.

${ }^{11}$ David Commins, Islamic Reform: Politics and Social Change in Late Ottoman Syria, New York 1990, pp. 111-115.
} 
authors 'Abd al-Rahman al-Kawakibi, Rashid Rida, and 'Abd al-Rahman Shahbandar incorporated desert Arabs into their conceptions of the Arab nation. Kawakibi's imaginary congress of Muslim delegates at Mecca, described in his 1900 treatise Umm al-Qura, included a distinguished delegate from Najd who embodied true Islam and the pure Arab character untainted by the moral decay that plagued urban Arabs living under tyranny. Writing at the same time, Rida also seized on the idea that desert Arabs possessed special virtues and a spirit of independence because they lived free of tyranny. A few years later, Shahbandar praised the Bedouins for their pure way of life and argued that Wahhabis deserved praise for championing Islam among the Bedouin. ${ }^{12}$

The shift in discourse on Arabian Bedouins and Wahhabis is well illustrated in a piece by a proponent of Arab cultural revival. ${ }^{13}$ Salah alDin al-Qasimi, the younger brother of the Salafi Jamal al-Din al-Qasimi, was part of the movement asserting that Arabs should occupy a more prominent role in Ottoman affairs. In 1909, Salah al-Din published a piece on the Wahhabis in the Egyptian periodical al-Muqtataf. He noted that "Wahhabi" had acquired a pejorative connotation at the hands of conservative 'ulama' striving to alienate common folk from the reformist 'ulama'. If a preacher merely recounted Prophetic traditions about shirk, then he was said to be a Wahhabi. The Egyptian newspapers al-Muqattam and al-Ahram were said to be "Wahhabi" publications, and an Arab cultural club was dubbed the Wahhabi Club. Al-Qasimi remarked that the efforts of conservative 'ulama' to alienate people from Wahhabism had the contrary effect of spurring greater interest in it, and as a result growing numbers were embracing it (tawahhab). In what he considered an effort to set the record straight, he gave a brief description of the Wahhabis. They were strict followers of the Hanbali school, avoiding all forms of shirk and devoting worship to God alone. Their 'ulama' exhibited upright behavior, seeking knowledge wherever it might be. Al-Qasimi expressed wonder at how their enemies could possibly accuse them of unbelief ( $k u f r)$, as they observed the pillars of Islam and followed the shari' $a$ in their daily lives. He asked if anyone had ever seen a Wahhabi drinking wine, consorting with prostitutes,

${ }_{12}$ Birgit Schaebler, "From Urban Notables to Notable Arabs," in Thomas Philipp and Christoph Schumann (eds.), From the Syrian Land to the States of Syria and Lebanon, Beirut 2004, pp. 177-178, 181-183, 193.

${ }^{13}$ For discussion of relations between these two groups in Damascus, see Commins, Islamic Reform, pp. 99-103. 
or embezzling funds from endowments (awqaf). As for Muhammad ibn 'Abd al-Wahhab, he brought nothing new. He just followed previous scholars. ${ }^{14}$

\section{Anti-Wahhabi Discourse}

While Salah al-Din al-Qasimi's article offers insight into the polemical uses of Wahhabism as a pejorative term, one must turn to religious publications to discern the evolution of the Wahhabi issue. The first specimen at hand is an item published in 1900 by one of the city's Hanbali scholars, Mustafa al-Shatti. ${ }^{15}$ It is not clear what prompted him to write this treatise, which covers themes commonly found in the anti-Wahhabi polemics of the nineteenth century. His treatise addresses five issues: independent legal reasoning (ijtihad), the two kinds of shirk and the categories of bid' $a$, the belief that holy men are alive in their graves, the permissibility of seeking help from prophets and the righteous be they living or dead, and the permissibility of visiting graves, especially that of the Prophet. There is nothing original or remarkable about the treatise. Thus in the section on ijtihad, al-Shatti referred to the Wahhabis as a group of self-proclaimed Hanbalis who performed ijtihad without a sound understanding of the Qur'an and the sunna and who therefore maintained incorrect beliefs on religious practices. ${ }^{16}$ The second item is a treatise by 'Ata al-Kasm published in 1901. At the outset, he wrote that an acquaintance of his had met with a Wahhabi who argued that it is forbidden to pray to the Prophet to approach God (tawassul). This acquaintance requested al-Kasm to provide proofs from the Quran, the sunna, and the writings of 'ulama' to support the consensus that tawassul is permitted. ${ }^{17}$ The treatise therefore consists of proof texts from those sources permitting tawassul of the Prophet. Once again, there is nothing in the treatise to distinguish it from customary anti-Wahhabi polemics.

\footnotetext{
${ }^{14}$ Muhibb al-Din al-Khatib, al-Duktur Salah al-Din al-Qasimi, 1305-1344: Safahat min ta'rikh al-nahda al-'arabiyya fi awa'il al-qarn al-ishrin, Cairo 1959, pp. 250-256. David Commins, Islamic Reform, pp. 101-102.

${ }_{15}$ Mustafa al-Shatti, al-Nuqul al-shari'yya fil-radd 'ala al-wahhabiyya, Damascus 1900.

${ }^{16}$ Ibid., pp. 6-7.

17 'Ata al-Kasm, al-Aqwal al-murdiya fil-radd 'ala al-wahhabiyya, Cairo 1901, p. 2.
} 
It may be the case that al-Shatti and al-Kasm were reacting against the early stirrings of the Salafi trend represented by Jamal al-Din al-Qasimi, 'Abd al-Razzaq al-Bitar, and Tahir al-Jaza'iri, but that is not altogether clear. Some light is shed on the question by Mustafa al-Shatti's younger kinsman, Muhammad Jamil al-Shatti in his 1920 biographical dictionary of Hanbalis. In commenting on controversy over the Wahhabis, he wrote that the Wahhabis wrongly branded other Muslims as infidels, while many of their foes went too far in stubbornly adhering to tradition. The correct way, in al-Shatti's view, was moderation, as taught by Jamal al-Din al-Qasimi. Al-Shatti also noted that a discussion of Wahhabism had taken place in Damascus in 1900-1901, notably represented by the two treatises at hand. Later, an Ottoman judge in Beirut, Yusuf al-Nabhani, composed a work condemning the period's religious reformers: Jamal al-Din al-Afghani, Muhammad 'Abduh, Rashid Rida, Mahmud al-Alusi, Khayr al-Din al-Alusi, and Mahmud Shukri al-Alusi. Shukri al-Alusi then rebutted al-Nabhani, who replied with another essay. Then a Najdi author, Sulayman ibn Sihman, entered a rebuttal against alNabhani's reply to al-Alusi. ${ }^{18}$ From this account, then, Mustafa al-Shatti and 'Ata al-Kasm were participating in a debate involving contributors from Egypt, Arabia, and several Ottoman provinces.

When we come to the later set of treatises, we find a mixture of customary polemics and new elements. The first item, published in 1911, is by Mukhtar ibn Ahmad Mu'ayyid al-'Azmi. ${ }^{19}$ He reiterated familiar themes from the anti-Wahhabi tradition, relying in large measure on a famous treatise by a nineteenth-century Meccan scholar, Ahmad Zayn al-Dahlan. Al-Dahlan's treatise repeated earlier reports that described Muhammad ibn 'Abd al-Wahhab as a rogue religious student who aspired to pose as a prophet in order to gain power. Once he had Saudi backing, he ordered the murder of his religious opponents and used force to impose his outrageous doctrine. The gist of his critique is that the Wahhabis rejected Islamic tradition and therefore do not belong to the community of believers. Their violence against lay Muslims and

${ }_{18}$ Muhammad Jamil al-Shatti, Mukhtasar tabaqat al-hanabila, Damascus 1920, pp. 139-140. For a discussion of Yusuf al-Nabhani, see Amal Ghazal, "Sufism, Ijtihad and Modernity: Yusuf al-Nabhani in the Age of "Abd al-Hamid II," Archivum Ottomanicum 19 (2001), pp. 239-272; Ghazal suggests 1908 or 1909 as the date of Nabhani's composition, p. 262; for a brief discussion of al-Nabhani's critique of the Wahhabis, pp. 270-271.

${ }_{19}$ Mukhtar ibn Ahmad Mu'ayyid al-'Azmi, Jala' al-awham 'an madhahib al-a'ima al-izam, Damascus 1911. 
'ulama' was a reflection of their infidel views. ${ }^{20}$ More interesting than al-'Azmi's conventional approach to condemning Wahhabism is his declared reason for composing the treatise. He stated that he wished to address his town's so-called enlightened faction, the mutanawwirun analyzed by James Gelvin. ${ }^{21}$ This faction represented the union of Salafi and Arabist tendencies that had formed in the few years before the 1908 constitutional restoration. Al-'Azmi belonged to the faction that Gelvin refers to as the mutadayyinun, or pious, which during the Ottoman constitutional era propagated its views in a Damascus periodical called al-Haqa'iq. The periodical typically defended religious beliefs and practices that Salafis and Wahhabis considered illegitimate innovations, and it warned against the excessive imitation of European ways. Al-'Azmi opened his treatise with an appeal to what the two factions, enlightened and pious, held in common-namely, the profession of faith and basic doctrines. He then asserted that his side affirmed well-established views and adhered to consensus positions whereas the "enlightened" followed doubtful views arising from their insistence on individual interpretation through ijtihad. ${ }^{22}$ In this instance, then, it looks as though the Wahhabi issue was assimilated to a factional struggle in Damascus, with al-'Azmi purporting to demonstrate the similarity of the "enlightened" camp's ideas on ijtihad and tawassul to those of the Wahhabis, perhaps to discredit them if not to persuade them to admit their errors.

The next spate of writings on the Wahhabis surfaced a decade later, after World War I. The Ottoman Empire had entered that war and suffered defeat, the victorious Western powers had divided the empire's remains, and an ephemeral Hashemite kingdom had fallen to French forces; but the alignment of religious factions in Damascus had persisted unchanged. The Wahhabi controversy of 1922 may have been set off when the Salafi activist and publisher Rashid Rida reportedly accepted payment from a Najdi merchant named 'Isa ibn Rumayh al-Uqayli to publish and distribute a volume of essays containing writings by Ibn Taymiyya, Ibn Qudama, and Ibn Rajab in Muhammad ibn 'Abd al-

\footnotetext{
${ }^{20}$ Ibid., pp. 4-8.

${ }^{21}$ On the "mutanawwirun" and the "mutadayyinun," see James Gelvin, "Post hoc ergo propter hoc? Reassessing the Lineages of Nationalism in Bilad al-Sham," in Philipp and Schumann (eds), From the Syrian Land to the States of Syria and Lebanon, pp. 127-142.

22 'Azmi, Jala' al-awham, p. 2.
} 
Wahhab's Kashfal-shubuhat. ${ }^{23}$ Exactly what prompted Rida to cooperate with this Najdi initiative is not clear; not is it clear who decided which treatises accompanied Ibn 'Abd al-Wahhab's essay. Rida's first visit to Damascus in 1908 had ended with a riot against him at the Umayyad Mosque, when a shaykh accused him of spreading Wahhabi doctrine. ${ }^{24}$ He had returned to Damascus during the Faysali period (1918-1920) to support the nascent Hashemite kingdom, but then returned to Egypt when France occupied Syria. Whether his publication of this volume represented an early phase of his turn to the Saudi cause or a provocation of his old 'ulama' adversaries, or both, or something else, it had the effect of stirring the debate between enlightened and pious camps anew.

One of the "pious" shaykhs associated with al-Haqa'iq, 'Abd al-Qadir al-Iskandarani, composed and published three anti-Wahhabi treatises, which in turn prompted a number of responses. In one treatise, alIskandarani resorted to the usual anti-Wahhabi arguments that had been rehearsed in the essays by al-Kasm, al-Shatti, and al-'Azmi, and reproduced proof texts from the Qur'an and the sunna in support of tawassul. In a more novel passage bearing on the Damascus context, al-Iskandarani wrote that one might forgive the people of Najd for following Muhammad ibn 'Abd al-Wahhab's errant doctrine because they were remote from the civilized world. They had a simple, coarse way of life and were utterly ignorant of rational sciences. Even their 'ulama' were barely familiar with the basics of Arabic. He related that he once met a high-ranking Najdi 'alim who came to Damascus to study grammar. His previous learning was such that Iskandarani placed him in lessons with beginners to study some elementary texts. Such was the level of learning among Wahhabi qadis and muftis. After denigrating the scholarly attainments of Wahhabi 'ulama', Iskandarani wondered how anyone in Damascus, a center of civilized life, could be fascinated with the simple doctrines of a band of Bedouins. In terms of the debate between the city's rival camps of "pious" and "enlightened," al-Iskandarani was scoring points against the "enlightened" by suggesting that they followed the views of the rustic Najdis. ${ }^{25} \mathrm{~A}$ second novel element in al-Iskandarani's treatise is his inclusion of an article from the newspaper

\footnotetext{
23 'Abd al-Qadir al-Iskandarani, al-Nafha al-zakiyya fi'l-radd 'ala shubuhat al-firqa al-wahhabiyya, Damascus 1922, p. 3.

${ }^{24}$ Commins, Islamic Reform, pp. 128-131.

25 Al-Iskandarani, al-Nafha, p. 7.
} 
Alif $B a$. This signifies the spread of religious polemic from the realm of madrasa, mosque, and specialized religious essays into the recently formed public sphere of the daily press. The article itself does not break new ground, but it is noteworthy that the newspaper had become a site of discursive contestation between the rival camps and the incorporation of the Wahhabi controversy into that setting. ${ }^{26}$

A second member of the "pious" camp, Muhammad Tawfiq ibn Najib al-Suqiya, entered the debate with a treatise that praised Iskandarani's refutation of the Wahhabi heresy. Al-Suqiya's essay is notable in three respects. First, he placed the controversy in the Damascus context by describing Rashid Rida's 1908 visit to the city. Al-Suqiya wrote that he attended Rida's lesson at the Umayyad Mosque and witnessed the incident when Shaykh Salih al-Tunisi denounced the visitor for spreading Wahhabi lies, forcing Rida to flee the city. To further blacken the reputation of Rida, and of the "enlightened" camp associated with him, al-Suqiya reported that Tunisi told him that Jamal al-Din al-Afghani had taught Muhammad 'Abduh, Rida's mentor, that the Qur'an is not God's word but the word of Abu Bakr. ${ }^{27}$ A second notable departure is al-Suqiya's defense of the belief that prophets, martyrs, and holy men are alive in their graves and that it is therefore sensible to seek their intercession. He wrote that European scientists had affirmed that souls are eternal and that it is possible to have contact with them and speak with them in one's sleep. ${ }^{28}$ This marks the entrance of modern science as a proof for the legitimacy of practices at saints' tombs, and it is significant because it indicates that "modern science" had acquired probative value in religious discourse. Furthermore, it appears that Suqiya included this "proof" because his "enlightened" adversaries viewed themselves as the vanguard of a modern generation in Syria that was familiar with European science. The third point worth noting is that al-Suqiya defended the Sufi $d h i k r$ ceremony and specifically named the Naqshbandi and Shadhili prayers as legitimate practices. ${ }^{29}$ This is direct evidence that elements in the city's Sufi orders were part of the "pious" campaign against the Wahhabis and their "enlightened" and Salafi defenders.

\footnotetext{
${ }^{26}$ Ibid., pp. 30-32.

${ }^{27}$ Muhammad Tawfiq al-Suqiya, Tabyin al-haqq wa'l-sawab fi'l-radd 'ala atba' Ibn 'Abd al-Wahhab, Damascus 1922, pp. 8-9.

${ }^{28}$ Ibid., p. 18.

${ }^{29}$ Ibid., pp. 28-31.
} 


\section{The Response to Wahhabism’s Critics}

As for those defenders, we have a treatise by the Salafi writer Muhammad Bahjat al-Bitar, published under the pseudonym Abu al-Yasar al-Dimashqi al-Maydani. Al-Bitar's work is notable in a number of respects. First, he claimed that his purpose was not to exacerbate divisions between Muslims but to close the gap between the two sides. Thus he wrote that it was one thing for Iskandarani to defend tawassul, but that he should not have slandered Najdis and Syrians; nor should he have included a defamatory account of Muhammad ibn 'Abd al-Wahhab's life. Bitar noted that al-Iskandarani in his lessons had publicly named 'ulama' of Damascus and branded them as Wahhabis to alienate people from them. When the head of the 'ulama' (al-Bitar does not name him) heard about this, he summoned al-Iskandarani and instructed him not to condemn individuals who had passed away and others still living. Al-Iskandarani denied that he had done so. It appears that al-Bitar was claiming the moral high ground by posing as a man seeking to bridge divisions while presenting al-Iskandarani as a sower of discord. ${ }^{30}$ Second, al-Bitar addressed al-Iskandarani's characterization of Najdis as uncouth barbarians unworthy of imitation by the civilized folk of Damascus. He posed the question of who was truly civilized. Consider, he suggested, that Najdis published and distributed thousands of copies of important books by Ibn Taymiyya, Ibn Qudama (two of the authors whose works Rida had published along with Ibn 'Abd al-Wahhab), and Ibn al-Qayyim, seeking no profit. By contrast, what did Damascenes have to boast of but miserliness, lies, pride, and hypocrisy? Which is better, the simple ways of Najd or the corrupt ways of Damascus? ${ }^{31}$ Third, al-Bitar wondered when al-Iskandarani and others in his camp would turn from criticizing fellow Muslims to show the same kind of zeal in rebutting Christian missionaries or teaching the new generation useful knowledge or establishing modern schools so the young generation would not need to attend foreign schools..$^{32}$ Fourth, al-Bitar admitted that some of the material in Ibn Rumayh's volume was misguided, notably the attribution of shirk and

${ }^{30}$ Abu al-Yasar al-Dimashqi al-Maydani (Muhammad Bahjat al-Bitar), Nazara fi risalat al-nafha al-zakiyya fil-radd 'ala shubah al-firqa al-wahhabiyya, Damascus 1922, pp. 3-6.

${ }^{31}$ Ibid., pp. 8-9.

${ }^{32}$ Ibid., p. 16. 
kufr to Muslims, but that should not prevent one who seeks truth from reading the volume for insight into illegitimate innovations and blameworthy practices associated with visiting graves. Al-Bitar agreed with the Wahhabi position that it is proper to view someone as an infidel if he stubbornly denies the truth of these matters after they have been clearly explained. But his discussion of the issue did not emphasize that point. Rather, he interpreted Muhammad ibn 'Abd al-Wahhab's views on shirk and kufr as an effort to dissuade people from illegitimate innovations and forbidden practices, to threaten people so they might abandon them. ${ }^{33}$

Al-Bitar's treatise is striking for his call on rival camps to emphasize common ground and overlook the points on which they differed. To illustrate that attitude, he presented a discussion that he claimed had taken place between a Salafi supporter of Ibn Taymiyya and a Sufi admirer of Ibn 'Arabi. The Salafi challenged the Sufi to defend Ibn 'Arabi's writings on union with God through mystical states (hulul and ittihad). The Sufi noted that Ibn 'Arabi clearly professed orthodox Islamic doctrine in many of his writings and that it was proper to interpret his teachings on mystical states in a way that did not violate texts in the Qur'an and the sunna about God's transcendence. In like manner, the Salafi maintained that if a Muslim prayed, fasted, paid the obligatory tax on wealth (zakat), and performed the pilgrimage yet put forth unconventional views on $k u f r$, then one should not emphasize the last point in evaluating him. In essence, al-Bitar called for the two sides to overlook the excesses of the rival camp in the interests of Muslim harmony. ${ }^{34}$

Along the same lines of urging forbearance, al-Bitar had written an article for the same Damascus newspaper, Alif $B a^{\prime}$, that published al-Iskandarani's essay. Under the heading of "Fairness Removes Controversy," al-Bitar called on the two sides to tone down their zeal and give up talk about burning writings they did not like. He disagreed with the Wahhabis for attributing shirk and kufr to believers for calling on holy men. Most of the time, it was simple-minded folk who did that with no intention of violating God's unity. Al-Bitar emphasized the difference between such believers and the polytheists of Muhammad's time, who called the Qur'an a lie and a bunch of fables, and ridiculed

33 Ibid., pp. $20-23$.
Ibid., pp. $23-25$. 
the Prophet as a poet, a madman, and a magician. Today's Muslims affirm the Qur'an is God's word while the polytheists of Muhammad's time fought against it. The essence of al-Bitar's position here is that the Wahhabis went too far in condemning those whose worship includes objectionable elements. ${ }^{35}$

On the other hand, al-Bitar criticized the Wahhabis' enemies for spreading false rumors. Thus the common folk of Damascus called the Wahhabis "Freemasons," which, he explained, meant atheists in common usage. How Wahhabis could be associated with atheists is puzzling, but it seems the notion arose because anti-Wahhabi authors asserted that the Wahhabis denied the sanctity of the prophets and holy men. Al-Bitar admitted that some Najdis regarded Muslims as infidels and that in turn other Muslims viewed them as infidels. It would be better, he maintained, if both sides refrained from such excess and treated each other with forbearance. ${ }^{36}$

A second treatise also broke new ground in searching for a middle way. Its author, Ahmad Fawzi al-Sa ati, had been the director of Telegraph and Post in Hijaz (whether for the Ottoman or Sharifian regime is unclear). During his posting to Hijaz, al-Sa ati became acquainted with Wahhabi 'ulama', their teachings, and their objections to other Muslims' religious practices. He presented his treatise as an effort to remove misunderstanding between Wahhabis and their foes. ${ }^{37} \mathrm{Al}-\mathrm{Sa}$ ati maintained that on matters of doctrine, there was no disagreement. It was only the strict Wahhabi prohibition of certain popular religious practices that created problems. He admitted that when commoners visited the tombs of holy men they might utter phrases that appeared to violate the command to worship God alone; but that was no reason to view all Muslims outside the Wahhabi domain as idolaters. Much of the treatise repeats familiar points on seeking intercession from the Prophet and holy men, visiting graves, and so forth. A novel twist is al-Sa'ati's assertion that later Wahhabi writers espoused more extreme views than Muhammad ibn 'Abd al-Wahhab. He noted that after Ibn 'Abd al-Wahhab's death, some Wahhabi 'ulama' took a copy of his writings to 'ulama' in Damascus, who declared that they conformed to the Qur'an and the sunna. Al-Sa 'ati concluded that it must have been later

35 Ibid., pp. 26-27.

36 Ibid., pp. 27-28.

37 Ahmad Fawzi al-Sa'ati, al-Insaffi da'wat al-wahhabiyya wa-khusumihim li-raf'alkhilaf, Damascus 1922, pp. 2-4. 
Wahhabis who declared most Muslims to be idolaters and asserted that only the people of Najd were followers of Islam..$^{38}$ As for the present situation, al-Sa ati maintained that disagreement between Wahhabis and other Muslims boiled down to the issue of intention. Wahhabis thought that belief in holy men was identical to belief in idols. But Muslims see holy men as God's servants, not as independent deities. Furthermore, if using holy men to approach God were prohibited, that would be stated in the Qur'an as clearly as the prohibition on murder. Since there was no clear prohibition, it must be considered permissible. ${ }^{39}$

Al-Sa ati proposed solutions to disagreements on visiting the Prophet's tomb in Medina and other matters, but the truly interesting aspect of his treatise comes at the very end and consists of two new twists in religious discourse. First, he called on Wahhabis to join with other Muslims to combat "materialists," who deny all religions and strive to lead youth away from religious studies. Instead of calling other Muslims idolaters and infidels, Wahhabis should unite with Muslims under the banner of the Qur'an and the sunna. Second, he lamented the idleness of Muslims as the cause of their incessant arguments. Instead of bothering with polemics, Muslims needed to study modern industrial skills, since they could not even manufacture a pin to patch a cloak. ${ }^{40}$

\section{Assessing the Meaning of the Controversy}

In conclusion, the first set of essays from 1900-1901 conform to a purely traditional mode of anti-Wahhabi discourse. They seem to stem from alarm at the appearance of the Salafi trend at that time, not at inroads made by Wahhabi discourse among Ottoman Muslims. Given the effective censorship regime under Sultan Abdülhamid II, the absence of any public defense of Wahhabi doctrine was natural. Twenty years later, a major shift had taken place in the religious discourses of Damascus, caused by a variety of factors: the maturation of the Salafi trend and emergence of the related Arabist trend; the formation of a coherent opposition to the Salafi-Arabist camp among so-called "pious" 'ulama', who broadcast their views in a periodical during the Ottoman constitutional period; the collapse of the Ottoman Empire; the tumultuous

\footnotetext{
38 Ibid., pp. 5-11.

39 Ibid., pp. 13-15.

40 Ibid., pp. 31-38.
} 
interval of Amir Faysal's rule, which witnessed the crystallization of popular and elite varieties of nationalism aligned with the "pious" and "enlightened" camps, respectively; and finally the advent of French rule. In this new context, al-Iskandarani and al-Suqiya went beyond the traditional arguments against Wahhabism by incorporating modern notions of civilization and science. In response, al-Bitar and al-Sa ati held that given the threats posed by missionaries, foreign schools, and European technical superiority, Muslims could not afford to waste time on religious polemics. They essentially contended that the Wahhabis were correct on some points and incorrect on others, and they upheld the Salafi camp's impulse to rectify popular religious practices they regarded as illegitimate innovations and reject the Wahhabi view of shirk and kufr. The "pious" camp, however, would not give ground, as al-Suqiya's staunch defense of Sufi prayers and ceremonies clearly indicated.

Given the absence of Wahhabis in Damascus, it is curious that Wahhabism should have become part of a polemical controversy. In reviewing at least a portion of the controversy (there could well be articles embedded in periodicals and other treatises), it is evident that the debate over intercessionary practices associated with Sufis and the tombs of holy men mattered deeply to the participants. There is no question of reading the religious discourse as a code for material interests. When Salafis took a fresh look at the Wahhabis and their teachings in the late 1800s, they were interested in uncovering shared intellectual roots (Ibn Taymiyya's school), not in finding an Arabian inspiration for their own convictions. Salafis and Wahhabis did find common ground in the rejection of what they considered illegitimate innovations in worship. They never closed the gap on the essential issue of excommunication. Defenders of customary Sufi practices may have been embedded in late Ottoman networks of power and patronage, but they too took the substance of religious belief quite seriously. The Wahhabi label provided a handy rhetorical club with which to strike their adversaries. One may consider them opportunistic in seizing the club; or one may consider the Salafis disingenuous in disavowing the association with Wahhabism. Authentic differences regarding what was "ideal" divided the two camps and their views of Wahhabism as well as the deployment of Wahhabism as a trope in their treatises.

That the debate evolved between 1900 and 1922 is worth noting, especially in view of the redundancy that characterized polemics on Wahhabism from the 1740s until the late 1800s. When Wahhabism's 
critics invoked modern scientific discoveries to defend Sufi beliefs, they were stepping away from a discourse entirely founded upon standard religious proof texts. Why? Because modern science had assumed an air of authority in Damascus, at least among young Syrians coming out of state schools. The ground of demonstrative proof was shifting, and one either shifted with it or conceded that ground to one's adversaries and allowed the weight of one's arguments to diminish. Another shift worth noting is how religious scholars and Arabist authors from the "enlightened" camp softened the hard edges of Wahhabi doctrine in their treatises, making the Najdi mission more palatable to Muslims of the Arab East. The Salafi rehabilitation of the Wahhabis' reputation paved the way for cooperation between such Salafi movements of the interwar period as the Muslim Brotherhood and the Wahhabis. In fact, during those decades when European domination reached its peak, squabbles over ritual increasingly appeared trivial compared to the massive threat to Islam that Western culture seemed to pose. ${ }^{41}$

${ }^{41}$ For a case study of Salafi-Sufi dynamics in Hamah in the late Ottoman and Mandate eras, see Itzchak Weismann, "The Politics of Popular Religion: Sufis, Salafis, and Muslim Brothers in 20th-Century Hamah," International Journal of Middle East Studies 37 (2005), pp. 39-58. 